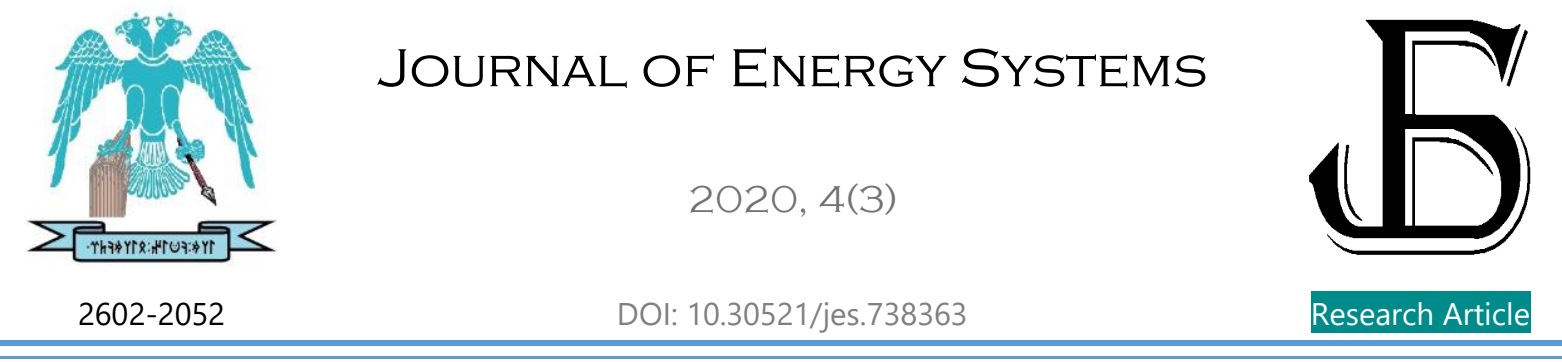

\title{
Using thermo-calc software to produce the phase diagram of $\mathrm{Zn}-\mathrm{Te}$ system
}

\author{
Shadia J. Ikhmayies \\ Jabal El-Hussain, Amman 11121, Jordan, shadia_ikhmayies@yahoo.com
}

$\begin{array}{rr}\text { Submitted: } & 16.05 .2020 \\ \text { Accepted: } & 30.08 .2020 \\ \text { Published: } & 30.09 .2020\end{array}$

\begin{abstract}
In this work, Thermo-Calc software 2019b is used to recalculate the liquidus-solidus phase diagram of the $\mathrm{Zn}$-Te binary system. The produced phase diagram is in good agreement with the experimental results found in the literature, and it shows five stable phases, which are elemental $\mathrm{Zn}$, elemental Te, $\mathrm{ZnTe}$ compound, $\mathrm{Zn}$ liquid, and Te liquid. A monotectic reaction is observed at monotectic temperature of $1479.14 \mathrm{~K}$ and 59.369 $\mathrm{Zn}$ mole percent, and a miscibility gap is found between 59.369 and $97.2781 \mathrm{Zn}$ mole percent above the monotectic temperature. Moreover, there are two eutectic reactions at the Te and $\mathrm{Zn}$ terminals. From this phase diagram, the maximum solubility of $\mathrm{ZnTe}$ in liquid $\mathrm{Zn}$ is determined as $2.7219 \%$ at $1479.14 \mathrm{~K}$. The melting points of $\mathrm{Te}, \mathrm{Zn}$, and stoichiometic $\mathrm{ZnTe}$ are found to be $722.587 \pm 0.025 \mathrm{~K}, 692.680 \pm 0.025 \mathrm{~K}$, and $1568.400 \pm 0.025 \mathrm{~K}$ respectively. These results are important for the development of preparation methods of $\mathrm{ZnTe}$, which is important for several industries including solar cells.
\end{abstract}

Keywords: $\quad$ Phase diagram, Solar cells, Thermo-calc software, Zinc tellurid,. Zn-Te binary system

Cite this paper as:

Ikhmayies, SJ., Using thermo-calc software to produce the phase diagram of Zn-Te system. Journal of Energy Systems 2020, 4(3), 88-95, DOI: 10.30521/jes.738363

(c) 2020 Published by peer-reviewed open access scientific journal, JES at DergiPark (https://dergipark.org.tr/en/pub/jes) 


\section{INTRODUCTION}

Knowledge of the phase diagram is essential for improvement of the materials properties, and development of preparation methods. Zn-Te binary system is one of the $\mathrm{Zn}$-chalcogen systems (i.e. $\mathrm{Zn}$ $\mathrm{Te}, \mathrm{Zn}-\mathrm{Se}$, and $\mathrm{Zn}-\mathrm{S})$. These systems are of considerable technological importance due to the semiconducting properties of the compounds $\mathrm{ZnTe}, \mathrm{ZnSe}$ and $\mathrm{ZnS}$ [1], which are of potential use in building electronic devices [2] and solar cells due to their interesting physical, electrical, and optical properties. The $\mathrm{Zn}$-Te system is very important in building electronic and optoelectronic devices. ZnTe is the sole intermediate compound in the $\mathrm{Zn}$-Te binary system, and this compound has a direct band gap of $2.26 \mathrm{eV}$ at room temperature [3], and low electron affinity of $3.53 \mathrm{eV}$ [4]. ZnTe has a cubic zincblende structure with space group $F 4 \overline{3} m$ and lattice constant $\mathrm{a}=6.101 \AA$ [5]. It has a p-type electrical conductivity which makes it a favorable p-type buffer layer in Cd-based hetero-junction solar cells $[6,7]$. The crystal of ZnTe has a good sensitivity in the green spectral region, which makes this material attractive for use in the fabrication of optoelectronic devices [4,8]. ZnTe is very important for different technologies such as optoelectronic and thermoelectric device technologies, in addition to solar cells and green-light-emitting diodes [9]. It is also used as a back contact [10] to CdTe-based solar cells in the superstrate device structure, and a buffer layer in these CdTe thin film solar cells. This is because of its chemical stability and the near-perfect alignment of its valence band gap and that of CdTe which, enables facile hole transport [11,12]. It is also used as the first unit in a tandem solar cell, a buffer layer for an $\mathrm{HgCdTe}$ infrared detector, and as a part of the graded p-Zn(Te)Se multiquantum-well structures in a blue-green laser diode [13-16].

The phase diagram of $\mathrm{Zn}$-Te binary system was produced by several authors such as $[1,2,17]$. Haloui et al. [17] determined it experimentally, and Feutelais et al. [2] calculated it with the program BINFKT [18]. However, these works are old, where they were published in 1997, and there are discrepancies between the results. The objective of this work is to produce a liquidus-solidus equilibrium phase diagram of ZnTe using the most recent database impeded in the Thermo-Calc software 2019b, and to compare the results with the results found in the literature. The importance of this study is inherent in; first, the importance of this phase diagram as a basis of crystal growth from melting substance, so it can benefit in improving preparation methods, and second in the importance of ZnTe for the industry of optical devices such as the yellow and green light emitting diodes and laser diodes, and the industry of optoelectronic devices such as electro-optical sensors [19] and solar cells.

\section{METHODOLOGY}

Thermo-Calc is a robust and flexible software and database package for all types of thermodynamic assessments such as phase equilibrium, phase diagram, and phase transformation calculations. In addition, with its application-oriented interface, many types of process simulations can be implemented [20]. Thermo-Calc software-2019b- is used to perform different kinds of thermodynamic and phase diagram calculations in equilibrium problems by the Calphad method [21], where this word was derived from the phrase (CALculation of PHAse Diagrams). The software is based upon a powerful Gibbs Energy Minimizer that utilizes Gibbs free energy minimization procedure to calculate phase equilibria and thermodynamic properties of a chosen system. The Calphad method is based on deriving the thermodynamic functions of a system from all available experimental data, where the thermodynamic functions are represented as polynomials of chemical composition and temperature. Then, the values of the polynomial coefficients are obtained using numerical optimization techniques [22,23]. The ThermoCalc software has two main components: the application itself, and the internally-consistent thermodynamic dataset it uses. For a given set of conditions, the computer determines the change in free 
energy for each possible combination of phases and phase compositions. Then, it selects the state that minimizes the total Gibbs free energy [24].

In this work as in the previous works [25-30], the template "Binary Calculation" with the type of calculation "phase diagram" was chosen to calculate the equilibrium phase diagram of the Zn-Te binary system. The total pressure is $1 \mathrm{bar}$, and temperature ranges are automatically selected. The used database is the TCBIN: TC Binary Solutions v1.1 database and just stable phases were credited.

\section{RESULTS AND DISCUSSION}

Fig.1a shows the liquidus-solidus phase diagram obtained in this work using Thermo-Calc 2019b Software. The phase diagram shows five stable phases, and seven fields; one single-phase field and six fields of two mixed phases, in addition to an intermediate compound line. The phases are Te solid (TRIGONAL_A8), Zn solid (HCP_ZN), ZnTe solid (B3_ZINCBLENDE) which is the line compound, Te liquid solution (LIQUID\#2) which is the chalcogen-rich solution ( $\mathrm{Zn}$ in Te) with constituents; $\mathrm{Te}$, $\mathrm{ZnTe}$, and $\mathrm{Zn}$, and $\mathrm{Zn}$ liquid solution (LIQUID) which is the metal-rich solution (Te in $\mathrm{Zn}$ ) with constituents; Zn, ZnTe, and Te. There are dormant gas phases that consist of (Te, $\mathrm{ZnTe}, \mathrm{Te}_{2}, \mathrm{Te}_{3}, \mathrm{Te}_{4}$, $\mathrm{Te}_{5}, \mathrm{Te}_{6}, \mathrm{Te}_{7}$, and $\mathrm{Zn}$ ), and they appear after high temperatures and depend on $\mathrm{Zn}$ mole percent. These phases don't appear in the phase diagram because they are not stable.

The one phase field is a liquid, and it appears in the upper part of the phase diagram as a white region, where this field extends over the whole composition range. The fields of two mixed phases are; Te solid + ZnTe solid or (B3_ZINCBLENDE+TRIGONAL_A8) between 0-50 Zn mole percent and $300 \mathrm{~K}$ to the melting temperature of Te, $(\mathrm{Zn}$ solid + ZnTe solid) or (B3_ZINCBLENDE+HCP_ZN) in the region restricted between 50-100 $\mathrm{Zn}$ mole percent and temperature range $300 \mathrm{~K}$ to melting temperature of $\mathrm{Zn}$, (Te liquid+ ZnTe solid) or (LIQUID\#2+B3_ZINCBLENDE) in the region between the melting points of Te and ZnTe and 0-50 Zn mole percent, (Zn liquid + ZnTe solid) or (LIQUID+B3_ZINCBLENDE) in the region limited by 50-100 Zn percent and melting temperatures of $\mathrm{Zn}$ and $\mathrm{ZnTe}$, (Te liquid $+\mathrm{ZnTe}$ solid) or (LIQUID\#2+B3_ZINCBLENDE) limited by 50-59.369 Zn mole percent and temperature range 1205.99-1568.400 K, and finally (liquid Te + liquid Zn) or (LIQUID+LIQUID\#2) in the region between 59.369-97.2781 Zn mole percent.

Fig.1b shows the experimental phase diagram of Zn-Te binary system obtained by Haloui et al. [17]. By Comparing Fig.1a with Fig.1b, it is found that there is good agreement between the present work and experimental work of Haloui et al. [17], where both phase diagrams have the same shape, show the same phases, and the same number of fields.

From Fig.1a, the melting points of $\mathrm{Te}$ and $\mathrm{Zn}$ are $722.587 \pm 0.025 \mathrm{~K}$ and $692.680 \pm 0.025 \mathrm{~K}$ respectively, while the temperature of the congruent melting of stoichiometric $\mathrm{ZnTe}$ is $1568.400 \pm 0.025 \mathrm{~K}$. These melting temperatures of pure elements are very close to the values found in [31], where the melting point of Te is $722.66 \mathrm{~K}$ and that of $\mathrm{Zn}$ is $692.677 \mathrm{~K}$. The melting point of $\mathrm{ZnTe}$ is approximately the same as the one obtained by Glazov and Pavlova [32], which is $1568 \mathrm{~K}$, but it is far from both the experimental value recorded by Feutelais et al. [2] which is $\mathrm{T}=1563 \pm 8 \mathrm{~K}$, and the calculated value obtained by them, which is $1570 \mathrm{~K}$. The melting temperature of $\mathrm{ZnTe}$ obtained in this work is the same as the accepted value, which is $1568 \mathrm{~K}$ [33], and this consistency is mainly due to the most recent database implemented in Thermo-Calc 2019b.

In addition, Fig.1a shows that there is a monotectic reaction:

$$
\text { Liquid \#2 } \stackrel{\text { Cooling }}{\longrightarrow} \text { Liquid }+ \text { ZnTe }\left(B 3 \_Z I N C B L E N D E\right)
$$


where the monotectic temperature is $1479.14 \mathrm{~K}$ at $59.369 \mathrm{Zn}$ mole percent. This reaction was experimentally determined by Feutelais et al. [2] at $\mathrm{T}=1480 \mathrm{~K}$. After this point (as seen in Fig.1a), there is a miscibility gap on the $\mathrm{Zn}$ rich side between 59.369 and $97.2781 \mathrm{Zn}$ mole percent above $\mathrm{T}=$ 1479.14 K, where the liquid solutions: liquid Te (Liquid \#2) and liquid Zn (liquid) are present in equilibrium, and they are immiscible in each other. The miscibility increases with temperature, and after $1855.75 \mathrm{~K}$ both liquids are completely miscible in each other and a homogeneous liquid is formed.
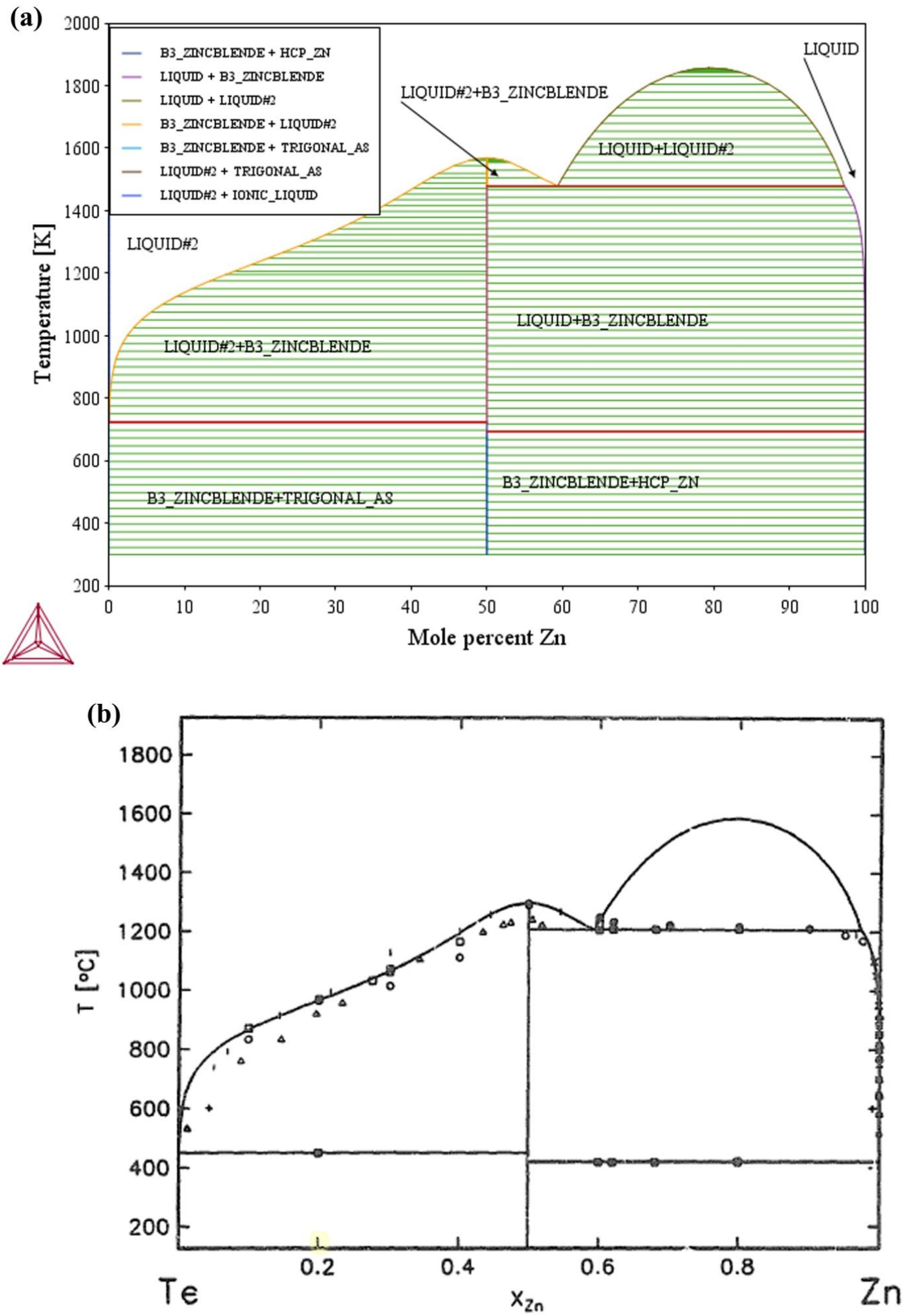

Figure 1. The phase diagram of Zn-Te binary system. a) Computed in this work using Thermo-Calc-2019b. b) Obtained experimentally. Reprinted after Haloui et al. [17]. Copyright () 1997 Published by Elsevier B.V. 
(a)

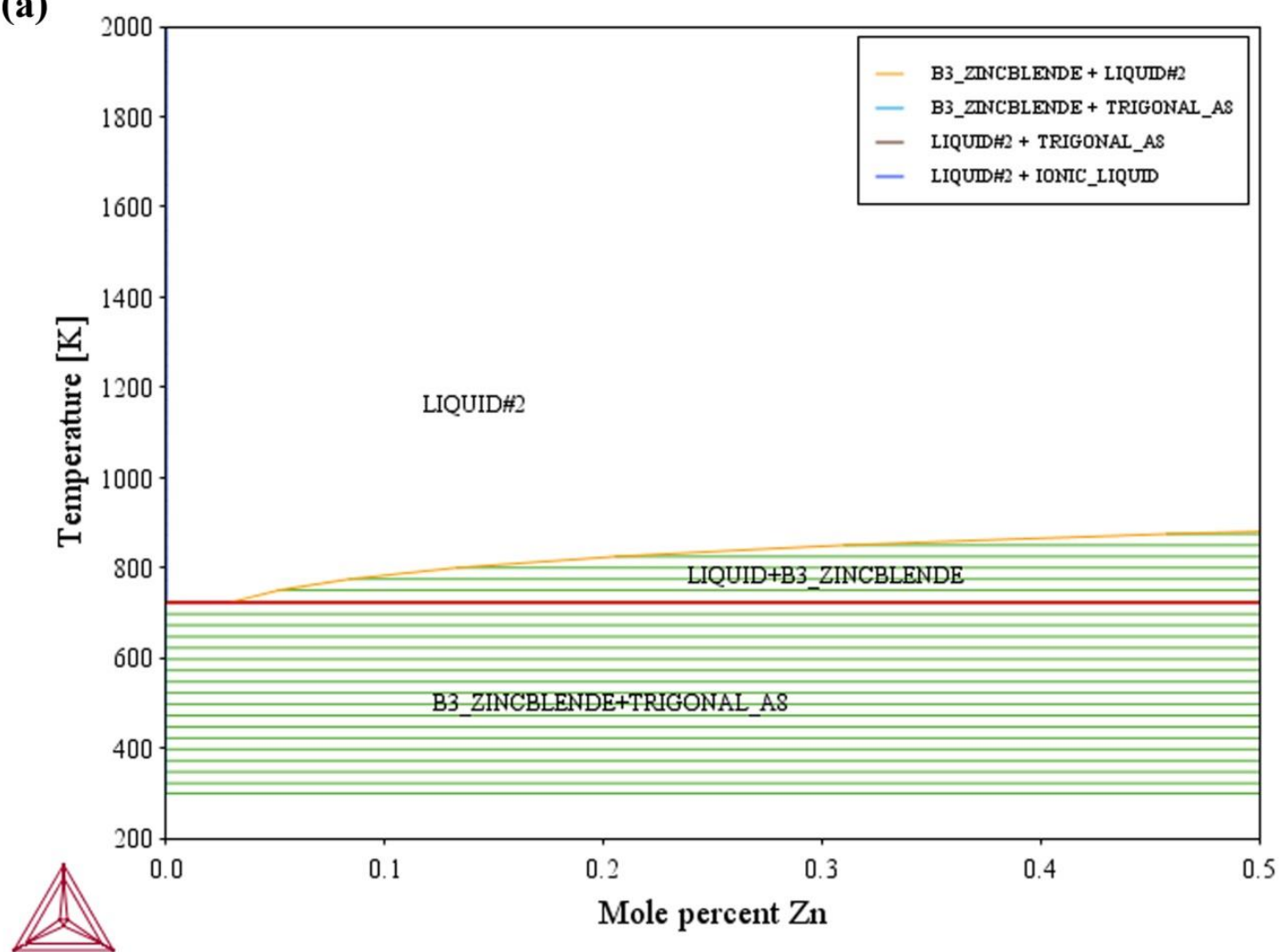

(b)

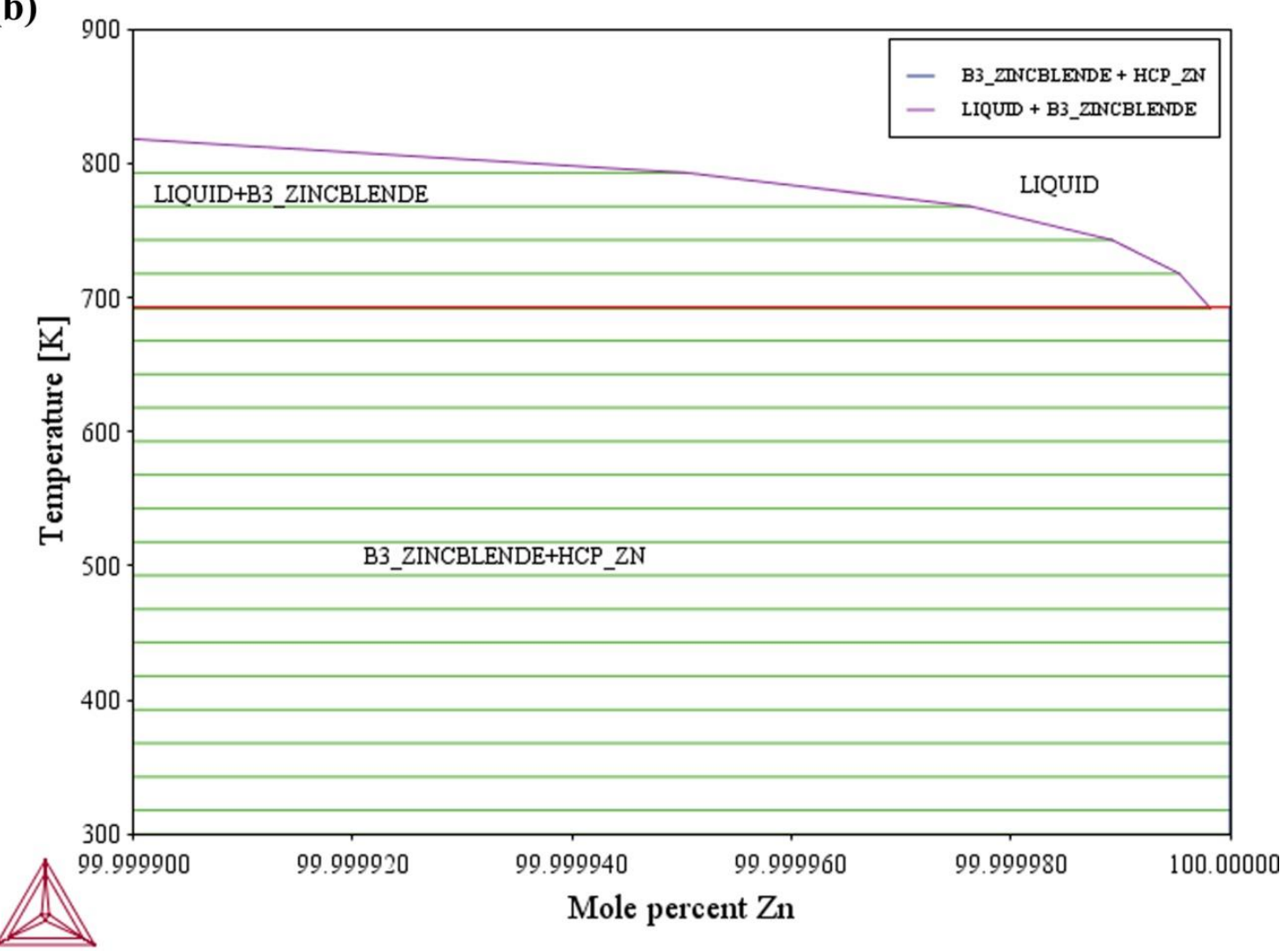

Figure 2. Enlarged portions of the phase diagram in Fig.la to show eutectic reactions. a) Te-rich side. b) Znrich side. 
Fig.2 displays enlarged portions of the terminals in Fig.1a, where Fig.2a shows the Te rich terminal and Fig. $2 \mathrm{~b}$ shows the $\mathrm{Zn}$-rich terminal. There are two degenerate eutectic reactions; the first one as seen in Fig.2a is:

$$
\text { Liquid } 2 \rightleftarrows T e+\text { ZnTe }
$$

which takes place at $\mathrm{T}=722.587 \pm 0.025 \mathrm{~K}$, and $0.029 \mathrm{Zn}$ mole percent. This result is approximately the same as the result of Feutelais et al. [2] who recorded this reaction experimentally at $\mathrm{T}=449.0 \pm 0.5^{\circ} \mathrm{C}$ which corresponds to $722.15 \mathrm{~K}$, and by computation at $449.4^{\circ} \mathrm{C}(722.55 \mathrm{~K})$.

The second reaction as seen in Fig. $2 \mathrm{~b}$ is:

$$
\text { Liquid } \rightleftarrows Z n+Z n T e
$$

at $692.680 \pm 0.025 \mathrm{~K}$ and about $100 \mathrm{Zn}$ mole percent. This result is slightly higher than the experimental result obtained by Feutelais et al. [2] who recorded this reaction experimentally at $\mathrm{T}=418.7 \pm 0.5^{\circ} \mathrm{C}$ which corresponds to $691.85 \mathrm{~K}$, but very close to their result obtained by computation at $419.6{ }^{\circ} \mathrm{C}$ (692.75 K).

The mutual solid solubilities of $\mathrm{Zn}$ and Te is essentially zero [23]. From Fig.2b the solubility of ZnTe in liquid Te starts from the melting point of Te and continues until $1855.75 \mathrm{~K}$, and the solubility of ZnTe in liquid $\mathrm{Zn}$ starts at the melting temperature of $\mathrm{Zn}$. The maximum solubility of $\mathrm{ZnTe}$ in liquid $\mathrm{Zn}$ obtained from Fig.2b is $2.7219 \%$ at $1479.14 \mathrm{~K}$, andt There are no experimental or computational numbers in the literature to compare this result with them.

\section{CONCLUSION}

The phase diagram of the $\mathrm{Zn}$-Te binary system was recalculated using Thermo-Calc 2019b software. The phase diagram showed five stable phases, which are; elemental $\mathrm{Zn}$ and $\mathrm{Te}, \mathrm{ZnTe}$ compound, liquid $\mathrm{Zn}$ and liquid Te. Melting points of $\mathrm{Zn}, \mathrm{Te}$, and $\mathrm{ZnTe}$ are determined and compared with experimental values found in the literature. Two degenerate eutectic reactions at the $\mathrm{Zn}$ and Te terminals and a monotectic reaction is found at $1479.14 \mathrm{~K}$ and $59.369 \mathrm{Zn}$ mole percent. A miscibility gap is observed in the range 59.369-97.2781 $\mathrm{Zn}$ mole percent above the monotectic temperature, where the two liquids (liquid $\mathrm{Zn}$ and liquid $\mathrm{Te}$ ) are immiscible in each other. The maximum solubility of $\mathrm{ZnTe}$ in liquid $\mathrm{Zn}$ is determined as $2.7219 \%$ at $1479.14 \mathrm{~K}$.

\section{REFERENCES}

[1] Sharma, R.C., Thermodynamic analysis and phase equilibria calculations for the $\mathrm{Zn}-\mathrm{Te}, \mathrm{Zn}-\mathrm{Se}$ and $\mathrm{Zn}-\mathrm{S}$ systems, J. Cryst. Growth, 1988, 88(2), 193-204.

[2] Feutelais, Y., Haloui, A., Legendre, B., A thermodynamic evaluation of the Te-Zn system, Journal of Phase Equilibria, 1997, 18(1), 48-61.

[3] Steininger, J., Strauss, A.J., Brebrick, R.F., Phase diagram of the Zn-Cd-Te ternary system, J. Electrochem. Soc.: Solid State Science, 1970, 117(10), 1305-1309.

[4] Suthar, D., Himanshu, Patel, S.L., Chander, S., Kannan, M.D., Dhaka, M.S., Enhanced physicochemical properties of ZnTe thin films as potential buffer layer in solar cell applications, Solid State Sciences (2020), doi: https://doi.org/10.1016/j.solidstatesciences.2020.106346.

[5] Haynes, W.M. (ed), CRC handbook of chemistry and physics (2nd ed.). Boca Raton, FL, USA: CRC Press, 2011, 12-80. 
[6] Li, J., Diercks, D.R., Ohno, T.R., Warren, C.W., Lonergan, M.C., Beach, J.D., Wolden. C.A., Controlled activation of $\mathrm{ZnTe}: \mathrm{Cu}$ contacted $\mathrm{CdTe}$ solar cells using rapid thermal processing, Sol. Energy Mater. Sol. Cells., 2015, 133, 208-215.

[7] Gessert, T.A., Asher, S., Johnston, S., Young, M., Dippo, P., Corwine, C., Analysis of CdS/CdTe devices incorporating a ZnTe:Cu/Ti Contact, Thin Solid Films, 2007, 515, 6103-6106.

[8] Hussain, T., Al-Kuhali, M.F., Durrani, S.M.A., Qayyum, H.A., Influence of angle deposition on the properties of ZnTe thin films prepared by thermal evaporation, Ceram. Int., 2018, 44(9), 10130-10140.

[9] Ashwini, P., Mani, J., Electronic and structural, properties of ZnTe using density functional theory (DFT), International Research Journal of Engineering and Technology (IRJET), 2018, 5(7), 2650- 2654.

[10] Feng, L., Wu, L., Lei, Z., Li, W., Cai, Y., Cai, W., Zhang, J., Luo, Q., Li, B., Zheng, J., Studies of key technologies for large area CdTe thin film solar cells, Thin Solid Films, 2007, 515, 5792-5797.

[11] Faulkner, B.R., Burst, J.M., Ohno, T.R., Perkins, C.L., To B., Gessert, T.A., ZnTe:Cu film properties and their impact on CdS/CdTe devices, 40th Photovoltaic Specialist Conference (PVSC) (8-13 June 2014, IEEE, Denver, Colorado, USA), 2014, 2321-2325.

[12] Uličná, S., Isherwood, P.J.M., Kaminski, P.M., Walls, J.M., Li, J., Wolden, C.A., Development of ZnTe as a back-contact material for thin film cadmium telluride solar cells, Vacuum, 2017, 139,159-163.

[13] Jie, J., Zhang, W., Bello, I., Lee, C.S., Lee, S.T., One-dimensional II-VI nanostructures: synthesis, properties and optoelectronic applications, Nano Today, 2010, 5(4), 313-336.

[14] Cao, Y.L., Liu, Z.T., Chen, L.M., Tang, Y.B., Luo, L.B., Jie, J.S., Zhang, W.J., Lee, S.T., Lee, C.S., Singlecrystalline ZnTe nanowires for application as high-performance green/ultraviolet photodetector, Opt. Express, 2011, 19(7), 6100-6108.

[15] Zhang, J., Rowland, C., Liu, Y., Xiong, H., Kwon, S., Shevchenko, E., Schaller, R.D., Prakapenka, V.B., Tkachev, S., Rajh, T., Evolution of self-assembled ZnTe magic-sized nanoclusters, J. Am. Chem. Soc., 2015, 137(2), 742-749.

[16] Kamran, M.A., Novel low-temperature synthesis and optical properties of 1D-ZnTe nanowires, Journal of Science: Advanced Materials and Devices, 2018, 3(2), 226-229.

[17] Haloui, A., Feutelais, Y., Legendre, B., Experimental study of the ternary system Cd-Te-Zn., Journal of Alloys and Compounds, 1997, 260(1-2), 179-192.

[18] Yu, T.C., Brebrick, R.F., The Hg-Cd-Zn-Te Phase Diagram, J. Phase Equilibria, 1992, 13, 476-496.

[19] Greenberg, J.H., PeTeX phase equilibrium and vapor pressure scanning of non-stoichiometry in the CdeZneTe system, Prog. Cryst. Growth Charact. Mater., 2003, 47, 196-238.

[20] Andersson, J-O., Helander, T., Hdghmd, L., Shi, P., Sundman, B., THERMO-CALC \& DICTRA, Computational tools for materials science, Calphad, 2002, 26 (2), 273-312.

[21] Introduction to Thermo-Calc, Thermo-Calc Documentation Set Thermo-Calc Version 2017a, http://www.thermocalc.com/media/40962/thermo-calc-documentation-set.pdf Page 97, Accessed at 5 September 2019.

[22] The CALPHAD methodology, Introduction to Thermo-Calc. http://www.thermocalc.com, 9/18/2016, Accessed at 5 September 2019.

[23] Computational Thermodynamics. Calculation of Phase Diagrams using the CALPHAD Method. http://www.calphad.com/calphad_method.html. 8/16/2019, Accessed at 5 September 2019.

[24] Boutwell, B.A., Thompson, R.G., Saunders N, Mannan, S.K., deBarbadillo, J.J., Phase formation modeling of an alloy casting using computational thermodynamics, 4th International Symposium on Superalloys and Derivatives (15-18 June 1997, Pittsburgh, Pennsylvania), 1997.

[25] Ikhmayies. S.J., Phase Diagram of In-P Binary System. In: Li J, Zhang M, Li B, Monteiro SN, Ikhmayies SJ, Kalay YE, Hwang J, Escobedo-Diaz JP, Carpenter JS, Brown AD, editors. Characterization of Minerals, Metals and Materials 2020, Cham, Switzerland: Springer International Publishing, 2020. pp. 283-288.

[26] Ikhmayies, S.J., Phase Diagrams of Al-Si System. In: Wang T, Chen X, Guillen DP, Zhang L, Sun Z, Wang C, Haque N, Howarter JA, Neelameggham NR, Ikhmayies S, Smith YR, Tafaghodi L, Pandey A, editors. Energy Technology 2019: Carbon Dioxide Management and Other Technologies. Cham, Switzerland: Springer International Publishing, 2019. pp. 231-237.

[27] Ikhmayies, S.J., Thermo-Calc of the Phase Diagram of the Fe-Si System. In: Sun Z, Wang C, Guillen DP, Neelameggham NR, Zhang L, Howarter JA, Wang T, Olivetti E, Zhang M, Verhulst D, Guan X, Anderson A, Ikhmayies S, Smith YR, Pandey A, Pisupati SV, Lu H, editors. Energy Technology 2018: Carbon Dioxide Management and Other Technologies. Cham, Switzerland: Springer International Publishing, 2018. pp. 471477.

[28] Ikhmayies, S.J., Thermo-Calc of the Phase Diagram of Calcium Silicon (Ca-Si) System. In: Sun Z, Wang C, Guillen DP, Neelameggham NR, Zhang L, Howarter JA, Wang T, Olivetti E, Zhang M, Verhulst D, Guan X, Anderson A, Ikhmayies S, Smith YR, Pandey A, Pisupati SV, Lu H, editors. Energy Technology 2018: Carbon Dioxide Management and Other Technologies. Cham, Switzerland: Springer International Publishing, 2018. pp. 489-494. 
[29] Ikhmayies, S.J., Thermo-Calc of the Phase Diagrams of the Nb-N System. In: Materials Society T, editors. TMS 2018 147th Annual Meeting \& Exhibition Supplemental Proceedings. Cham, Switzerland: Springer International Publishing, 2018. pp. 755-760.

[30] Ikhmayies S.J., Phase Analysis of the $\mathrm{Si}_{-} \mathrm{O}_{2}$ System. In: Zhang L, Drelich JW, Neelameggham NR, Guillen DP, Haque N, Zhu J, Sun Z, Wang T, Howarter JA, Tesfaye F, Ikhmayies S, Olivetti E, Kennedy MW, editors. Energy Technology 2017: Carbon Dioxide Management and Other Technologies. Cham, Switzerland: Springer International Publishing, 2017. pp. 333-342.

[31] Periodic Table, Royal Society of Chemistry, 2019, http://www.rsc.org/periodic-table/. Accessed at 7 September 2019.

[32] Glazov, V.M., Pavlova, L.M., Volumetric effects of ZnTe, CdTe and HgTe compounds at melting and subsequent heating, Scandinavian Journal of Metallurgy, 2001, 30(6), 379-387.

[33] Haynes, William M, editors. CRC Handbook of Chemistry and Physics, 92nd ed., Boca Raton, FL, CRC Press, 2011. pp. 12.80. 